\title{
ANALYZING THE RELIGIOUS VALUES IN A NOVEL ENTITLED HAFALAN SHALAT DELISA BY TERE LIYE
}

\author{
Diyah Zulfa Jauhara ${ }^{1}$, Eka Sari Setianingsih ${ }^{2}$, Moh. Aniq Khairul Basyar ${ }^{3}$ \\ 1,2,3 Universitas PGRI Semarang, Jepara, Indonesia \\ ${ }^{1}$ zulfajauharadiyah@yahoo.com, ${ }^{2}$ ekasari129@yahoo.com, ${ }^{3}$ mohaniqkhb@gmail.com
}

\begin{abstract}
The background of the research problem was that some parents were less concerned with the religious values of their children. Many children did not care about their religious activities such as the lack of interest in memorizing prayers and reciting the Qur'an. The problem in this research was the religious values contained in Tere Liye's novel "Hafalan Shalat Delisa". The purpose of this research was to reveal and describe the religious values found in Tere Liye's "Hafalan Shalat Delisa" novel. This research was qualitative research using a qualitative descriptive method by describing events, character attitudes, as well as dialogue between characters using note taking techniques. The validity of the data was measured through source triangulation. The results showed that there were several religious values found in "Hafalan Shalat Delisa", a novel by Tere Liye, namely faith, morals, and worship.
\end{abstract}

Keywords: analysis, religious values, novel

\section{ANALISIS NILAI RELIGIUS PADA NOVEL HAFALAN SHALAT DELISA KARYA TERE LIYE}

\begin{abstract}
ABSTRAK
Latar belakang masalah yang mendorong penelitian ini adalah sebagian orangtua kurang peduli dengan nilai keagamaan anaknya. B anyak anak-anak yang kurang peduli dengan kegiatan keagamaan seperti kurang minat untuk menghafalkan doa-doa shalat dan membaca Al Qur'an. Permasalahan dalam penelitian ini adalah Apa saja nilai religius dalam novel Hafalan Shalat Delisa karya Tere Liye? Tujuan dari penelitian ini adalah mengetahui dan mendeskripsikan nilai religius dalam novel Hafalan Shalat Delisa karya Tere Liye. Jenis penelitian ini adalah penelitian kualitatif menggunakan pendekatan kualitatif metode deskriptif dengan memaparkan kejadian, sikap tokoh, maupun dialog antar tokoh dengan teknik simak catat. Keabsahan data yang digunakan adalah triangulasi sumber. Hasil penelitian menunjukkan terdapat nilai religius dalam novel Hafalan Shalat Delisa karya Tere Liye yaitu keimanan, akhlak, dan ibadah.
\end{abstract}

Kata Kunci: analisis, nilai religius, novel

\begin{tabular}{|c|c|c|}
\hline Submitted & Accepted & Published \\
\hline 08 Oktober 2020 & 15 Juli 2021 & 28 Juli 2021 \\
\hline
\end{tabular}

\begin{tabular}{|l|c|c|c|}
\hline Citation & $:$ & $\begin{array}{l}\text { Jauhara, D.Z., Setianingsih, E. S., \& Basyar, M. A. K. (2021). Analyzing the Religious Values in a Novel Entitled Hafalan } \\
\text { Shalat Delisa by Tere Liye. Jurnal PAJAR (Pendidikan dan Pengajaran), 5(4), 1028-1036. DOI : } \\
\text { http://dx.doi.org/10.33578/pjr.v5i4.8173. }\end{array}$ \\
\hline
\end{tabular}

\section{PENDAHULUAN}

Pada era globalisasi budaya asing dari luar sudah banyak memberikan dampak perubahan pada kehidupan masyarakat Indonesia. Hal yang perlu diperhatikan dari era globalisasi ini adalah sikap penerimaan masyarakat terhadap masuknya budaya asing agar tidak terlarut didalamnya. Masyarakat terkadang tidak mempertimbangkan bahwa dengan perkembangan teknologi dan zaman modernisasi ini selain membawa dampak yang baik juga terdapat dampak yang buruk. Dengan adanya globalisasi masyarakat akan menjadi konsumerisme dan hidup kebarat-baratan (westernisasi).(Gunawan, 2020).
Karya sastra merupakan karya imajinatif yang dituangkan oleh pengarang dalam bentuk tulisan yang mempunyai nilai keindahan. Karya imajinatif tersebut terlahir dari kreasi dan juga daya khayal pengarang. Karya sastra merupakan penjabaran kehidupan dan pengalaman pengarang atas kehidupan disekitarnya karya sastra diciptakan bukan sekedar untuk dinikmati melainkan juga untuk dimanfaatkan guna mengembankan imajinasi dan fantasi sehingga dapat meningkatkan kualitas pembaca (Burhan Nurgiyantoro, 2012). Karya sastra dapat dijadikan sebagai alat untuk meningkatkan kecerdasan 
sekaligus untuk pembentukan kepribadian seseorang. Oleh karena itu, dalam karya sastra ditampilkan berbagai macam persoalan nilai luhur, cara hidup, etika, dan norma-norma masyarakat sehingga dapat dijadikan media pendidikan.(Fitriana, 2013)

Sebagian orangtua kurang peduli dengan nilai keagamaan anaknya. Banyak anak-anak yang kurang peduli dengan kegiatan keagamaan seperti kurang minat untuk menghafalkan doa-doa shalat dan membaca Al-Qur'an. (Regar et al., 2012)

Dalam penelitian ini, peneliti mengkaji novel Hafalan Shalat Delisa karya Tere Liye yang tersirat nilai religius didalamnya yaitu keimanan, akhlak, dan ibadah. Novel Hafalan Shalat Delisa, ditulis oleh Tere Liye. Karya-karya dari Tere Liye selalu menjadi best seller. Tere Liye lebih dominan menulis tentang serial anak-anak, karena segala proses pendidikan yang baik pasti dimulai dari masa kanak-kanak.(Prastica \& Wulandari, 2020)

Novel Hafalan Shalat Delisa merupakan novel berbasis anak-anak yang didalamnya menggambarkan model pendidikan di lingkungan keluarga yang variatif dan inspiratif di Lhok Nga. Novel ini termasuk pada novel anak dan keluarga yang penuh dengan nilai-nilai pendidikan dan moral. Novel Hafalan Shalat Delisa dapat mengajarkan para pembaca untuk selalu bersabar dalam menghadapi persoalan.(Wanispa \& Hidajati, 2018)

Berdasarkan uraian di atas penelitian ini dilakukan untuk mengetahui nilai-nilai religius yang terkandung dalam novel Hafalan Shalat Delisa karya Tere Liye yang selanjutnya nilai-nilai religius tersebut dapat diimplementasikan dalam kehidupan anak-anak dan novel Hafalan Shalat Delisa dapat dijadikan referensi sebaga media dalam menanamkan nilai religius pada anak. Berdasarkan konteks penelitian di atas peneliti ingin mengadakan penelitian dengan judul "Analisis nilai religius dalam novel Hafalan Shalat Delisa".

\section{KAJIAN TEORETIS}

\section{Analisis}

Analisis merupakan cara berfikir secara sistematis terhadap sesuatu untuk menentukan bagian, hubungan antar bagian, dan hubungannya dengan keseluruhan. Berdasarkan pendapat tersebut pengertian analisis dalam kaitannya dengan penelitian ini adalah suatu kegiatan menelaah buku dan menjabarkan suatu aspek tertentu secara mendalam untuk menilai buku dengan mencari data yang terdapat pada buku secara sistematis dengan menggunakan berbagai teknik pengumpulan data kemudian hasil penemuan tersebut diinformasikan kepada orang lain. Jadi, analisis yang dimaksud dalam penelitian ini adalah memaparkan jenis-jenis nilai religius yang terdapat dalam novel Hafalan Shalat Delisa karya Tere Liye (Sugiyono, 2017).

\section{Nilai}

Nilai pada hakekatnya adalahh sifat atau kualitas yang melekat pada suatu objek bukan objek itu sendiri. Sesuatu itu mengandung nilai artinya ada sifat atau kualitas yang melekat pada sesuatu itu. Jadi nilai yang dimaksud dalam penelitian ini adalah sesuatu yang melekat atau sifat yang ada pada religius kehidupan yang ada dalam novel Hafalan Shalat Delisa karya Tere Liye (Kaelan, 2014).

\section{Religius}

Religius harus dibedakan dari pengertian agama. Kata religious menurut asalnya berarti ikatan atau pengikatan diri, sedangkan agama terbatas pada ajaran-ajaran (doctrines) dan peraturan- peraturan (law) (Subijantoro Atmosuwito, 2017).

Religius adalah segala sistem perbuatan manusia untuk mencapai suatu maksud dengan cara menyadarkan diri kepada kemauan dan kekuasaan makhluk-makhluk halus seperti ruh, dewa, dan sebagainya yang menempati alam (Mangunwijaya, 2017). Diperkuat pendapat (Burhan Nurgiyantoro, 2012) menyatakan bahwa religius dan agama memang erat berkaitan, 
berdampingan bahkan dapat melebur menjadi satu kesatuan, namun keduanya memiliki makna yang berbeda.

Religius adalah penghayatan keagamaan seseorang dan keyakinannya terhadap adanya Tuhan yang diwujudkan dengan mematuhi perintah dan menjauhi larangan dengan keikhlasan hati dan dengan seluruh jiwa dan raga. Religius adalah suatu keadaan yang ada dalam diri seseorang yang mendorongnya bertingkah laku dan bersikap sesuai ajaran agamanya yang terlihat dalam kegiatan sehari-hari.

\section{Nilai Religius}

Nilai religius adalah nilai mengenai konsep kehidupan religius atau keagamaan berupa ikatan atau hubungan yang mengatur manusia dengan Tuhannya.Nilai religius juga berhubungan dengan kehidupan dunia tidak jauh berbeda dengan nilai-nilai lainnya seperti nilai kebudayaan dan aspek sosial, selain itu nilai religius juga erat hubungannya dengan kehidupan akhirat. Kehidupan akhirat inilah yang membedakan dengan nilai-nilai lainnya.

Nilai religius adalah nilai-nilai yang terdapat dalam karya sastra fiksi berupa penentuan manusia yang berhati nurani, berakhlak mulia atau saleh ke arah segala makna yang baik. Bagi manusia religius, terdapat makna yang harus dihayati suci dan nyata dalam bentuk kekuasaan dan kekuatan yang tidak terhingga, sumber hidup dan kesuburan. Sesuatu yang dapat dihayati manusia religius yakni kesadaran batin, mensyukuri nikmat yang telah diberikan Tuhan berupa sumber kehidupan dan kesuburan bagi manusia (Mangunwijaya, 2017).

Adanya pembudayaan tadarus di sekolah dapat meningkatkan nilai karakter religius siswa. Hal itu sesuai dengan ajaran Allah SWT dalam islam yang menganjurkan setiap umat-Nya untuk membaca Al-Qur'an. Pada kegiatan tadarus kita disuruh untuk meneladani karakter-karakter (akhlak) Allah SWT. Al-Qur'an mempunyai pengaruh yang sangat kuat terhadap jiwa manusia. Demikian pula terhadap jiwa anak-anak. Semakin jernih jiwa anak, maka semakin bertambah pula kecerdasan spiritualnya. Pembiasaan kegiatan tadarus berpengaruh terhadap sikap-sikap positif karena ketika membaca Al-Qur'an diibaratkan berkomunikasi langsung dengan Allah Sang Maha Pencipta (Fitri Damayanti, Eka Sari Setianingsih, 2019).

Dalam agama Islam, ada tiga pokok ajaran Islam, sebagaimana yang telah diketahui bahwa ajaran Islam adalah seluruh ajaran Allah yang berdasarkan Al-Quran dan sunah Nabi SAW. Ajaran Allah yang dimaksud tersebut di atas berupa tiga pokok ajaran Islam yang meliputi:

\section{a. Keimanan}

Atas dasar keimanan itulah seseorang dituntun dalam berperilaku, oleh sebab itu bilamana keimanannya benar maka perilakunya akan benar pula, demikian pula sebaliknya dari keimanan yang keliru akan lahirlah perilaku yang keliru (Sudarsono, 2017). Adapun rukun iman ada enam, yaitu :

1) Iman kepada Allah

2) Iman kepada Malaikat

3) Iman kepada Rosul

4) Iman kepada Kitab Allah

5) Iman kepada Hari Akhir / Kiamat

6) Iman kepada Qadha' dan Qadhar

\section{b. Akhlak}

Berbicara pada tatanan akhlak tentu tidak dapat dipisahkan dengan manusia sebagai sosok ciptaan Allah yang sangat sempurna.Akhlak adalah mutiara hidup yang membedakan makhluk manusia dengan makhluk hewani. Manusia tanpa akhlak akan hilang derajat kemanusiaannya sebagai makhluk Allah yang paling mulia, menjadi turun ke martabat hewani. Manusia yang telah lari dari sifat insaniyah adalah sangat berbahaya dari binatang buas.

\section{c. Ibadah}

Ibadah sesungguhnya merupakan manifestasi rasa syukur yang dilakukan manusia terhadap Tuhannya. Ibadah disebut juga sebagai ritus atau perilaku ritual. Ibadah adalah bagian 
yang sangat penting dari setiap agama atau kepercayaan, seperti yang dan pada sistem-sistem kultus (Madjid, 2017).

\section{Novel}

(Tim Penyusun Kamus, 2015) novel diartikan sebagai karangan prosa yang panjang, mengandung rangkaian cerita kehidupan seseorang dengan orang disekelilingnya dengan menonjolkan sifat perilaku dan watak. Novel dapat menjadi media yang efektif untuk menanamkan dan mengembangkan nilai-nilai pendidikan (edukatif), terutama pendidikan religius.

(Burhan Nurgiyantoro,

mengungkapkan novel sebagai sebuah karya fiksi menawarkan sebuah dunia, dunia yang berisi model kehidupan yang diidealkan, dunia imajinatif yang dibangun melalui berbagai unsur intrisiknya seperti peristiwa, plot, tokoh, latar, sudut pandang, dan lain-lain yang kesemuanya tentu saja juga bersifat imajinatif.

Berdasarkan uraian di atas, dapat dikatakan bahwa novel adalah salah satu bentuk karya sastra prosa yang menceritakan kehidupan dalam bentuk cerita yang lebih luas baik dalam menampilkan tokoh-tokoh serta pendapat latar yang menunjukkan terjadinya serangkaian peristiwa.

Unsur-unsur pembangun novel terdiri dari unsur instrinsik dan unsur ekstrinsik. Unsur intrinsik adalah unsur yang membangun dari dalam novel yang terdiri dari tema, alur, setting, amanat, tokoh, dan penokohan (Burhan Nurgiyantoro, 2012).

(Burhan Nurgiyantoro, 2012) unsur ekstrinsik adalah unsur yang berada di luar karya sastra itu. Unsur ekstrinsik walaupun menjadi pembangun dari luar tetapi berpengaruh dalam membangun karya sastra. Oleh karena itu, unsur ekstrinsik dalam sebuah novel haruslah tetap dipandang sebagai suatu yang penting.

Pada penelitian ini unsur-unsur intrinsik hanya difokuskan pada unsur tokoh dan penokohan, latar cerita (setting), alur cerita, dan amanat. Hal itu didasarkan pada pertimbangan bahwa penelitian ini bukan pada analisis unsurunsur intrinsik novel Hafalan Shalat Delisa secara detail, melainkan pada nilai religi.

Novel dilihat dari segi mutu dibedakan atas novel literer dan novel populer. (Endang Hidayat Widjojoko, 2016) menggolongkan novel atas : novel romantik, novel petualang, novel sejarah, novel absurd, novel binatang, novel humor, novel horor, novel sindiran, novel detektif / kriminal, novel perang, novel misteri, novel western, novel spionase.us yang terkandung dalam novel Hafalan Shalat Delisa karya Tere Liye.

\section{Novel Hafalan Shalat Delisa}

Novel Hafalan Shalat Delisa yang dimaksud dalam penelitian ini adalah novel Hafalan Shalat Delisa karya Tere Liye yang diterbitkan oleh penerbit Republika, Jakarta Selatan tahun 2017 cetakan XXIX.

\section{Sastra Anak}

Sastra anak adalah sastra yang secara emosional psikologis dapat ditanggapi dan dipahami oleh anak, dan itu pada umumnya berangkat dari fakta yang kongkrit dan dapat diimajinasikan (Burhan Nurgiyantoro, 2005). Berdasarkan uraian diatas, cerita yang dikisahkan dalam sastra anak, tidak harus cerita yang berkaitan dengan dunia anak. Kisah dari kehidupan makhluk lain juga bisa diceritakan asalkan isinya sesuai dengan sudut pandang anak. Kreatifitas dan variasi dalam sastra anak sangat penting karena dapat meningkatkan minat baca pada anak.

Sastra bisa menjadi permainan menyeimbangkan segenap kemampuan mental manusia. Berdasarkan uraian di atas, sastra merupakan sesuatu yang memiliki kekhasan yang terjadi dalam kehidupan masyarakat untuk lebih memanusiakan manusia dan menyeimbangkan mental masing-masing di berbagai permasalahan kehidupan yang ada (Agus Wibowo, 2013). 


\section{Genre Sastra Anak}

Lukens dalam (Burhan Nurgiyantoro, 2005) mengelompokkan genre sastra anak ke dalam enam macam, yaitu realisme, fiksi formula, fantasi, sastra tradisional, puisi, dan nonfiksi dengan masing-masing mempunyai beberapa jenis lagi.

\section{METODE PENELITIAN}

Penelitian ini menggunakan metode penelitian kualitatif. Dalam penelitian ini pendekatan yang digunakan adalah metode deskriptif, studi kepustakaan, dan metode analisis. Metode deskriptif dalam penelitian ini, peneliti akan menjabarkan mengenai gambaran kehidupan sosial, karakter tokoh yang ada dalam novel, dan menganalisis serta mencatat hal-hal yang diperlakukan dalam menunjang penelitian kualitatif. Studi kepustakaan yang dilakukan peneliti adalah dengan membaca referensi bukubuku yang akan dikaji. Buku yang akan dikaji harus berhubungan dengan isi dari penelitian yang dilakukan. Metode analisis yang digunakan dalam penelitian ini yaitu dengan membaca secara cermat isi nilai religius dari novel Hafalan Sholat Delisa kemudian mencatat hal-hal yang penting dalam bacaan.

Tempat penelitian yang digunakan dalam penelitian ini yaitu di belakang meja. Artinya aktivitas peneliti mulai dari mengumpulkan sampai menganalisis data dilakukan di suatu tempat yang hening, cukup luas, dan nyaman. Sumber data akan digunakan dalam penelitian ini yaitu novel Hafalan Shalat Delisa karya Tere Liye dengan jumlah halaman 266. Latar penelitian yang digunakan adalah novel Hafalan Shalat Delisa yang diterbitkan oleh Republika pada tahun 2017 cetakan XXIX.

Data yang digunakan dalam penelitian ini adalah berupa kutipan-kutipan kata atau kalimat dalam bagian cerita novel Hafalan Sholat Delisa karya Tere Liye dan deskripsi dari perilaku atau tindakan tokoh dalam cerita. Sumber data primer dari penelitian ini adalah Novel Hafalan Shalat Delisa Karya Tere Liye yang diterbitkan oleh penerbit Republik, Jakarta Selatan tahun 2017 dengan jumlah halaman 266. Sumber data sekundernya adalah buku-buku yang menunjang dan berkaitan dengan penelitian tersebut. Penelitian kualitatif yang menjadi instrumen atau alat penelitian adalah peneliti itu sendiri.

Penelitian ini akan menggunakan metode simak dengan teknik catat untuk membantu pengisian dalam kartu data. Metode simak dengan teknik catat yaitu mengumpulkan data dengan cara mengumpulkan informasi nilai religius yang terdapat pada novel. Metode simak dengan teknik catat dirasa sangat membantu dalam memproses data, dalam hal ini untuk menganalisis nilai religius yang terdapat dalam novel Hafalan Shalat Delisa Karya Tere Liye dilanjutkan dengan mencatat halhal penting dari novel tersebut yang berkaitan dengan kebutuhan penelitian.

Sebuah penelitian memerlukan pengecekan keabsahan. Pengujian keabsahan data metode kualitatif berbeda dengan penelitian kuantitatif. Pada penelitian ini, peneliti menggunakan teknik peningkatan ketekunan dalam penelitian dan triangulasi untuk mengecek keabsahan data. Peneliti lebih meningkatkan ketekunan melalui membaca kembali dokumendokumen yang berkaitan dengan temuan yang diteliti sehingga mampu memperluas dan mempertajam wawasan agar dapat digunakan untuk memeriksa data yang ditemukan itu benar/dipercaya atau tidak. Dokumen yang dimaksud yaitu berupa pengumpulan data. Triangulasi yang digunakan oleh peneliti adalah triangulasi sumber. (Sugiyono, 2017) menyatakan bahwa triangulasi sumber yaitu untuk menguji kredibilitas data yang dilakukan dengan cara mengecek data yang diperoleh melalui beberapa sumber. Data dari beberapa sumber akan dideskripsikan dan dikategorikan untuk mendapat kesimpulan yang sama. Narasumber yang diajukan yaitu guru SD, siswa SD, dan orang tua siswa SD.

Teknik analisis digunakan untuk mencari pola hubungan mengenai hal-hal yang ingin diketahui oleh peneliti sehingga akan lebih mudah dalam menyusun dan melaporkan hasil penelitian. 
(Sugiyono, 2017) menjelaskan bahwa aktivitas dalam analisis data kualitatif dilakukan secara interaktif dan berlangsung secara terus menerus sampai tuntas, sehingga datanya sudah jenuh. Aktivitas dalam analisis data tersebut yaitu data reduction (reduksi data), data display (penyajian data), dan conclusion (kesimpulan). Reduksi data yang peneliti lakukan yaitu peneliti memilih dan merangkum hal-hal pokok dari novel Hafalan Shalat Delisa Karya Tere Liye yang berbentuk cerita maupun percakapan. Data dari novel Hafalan Shalat Delisa kemudian dianalisis. Dalam display data peneliti berusaha menyusun data yang relevan sehingga informasi yang dapat disimpulkan dan memiliki makna tertentu untuk menjawab masalah penelitian. Analisis data ini dimaksudkan sebagai kegiatan penelaah, pengkajian, atau penyelidikan terhadap berupa data yang berupa nilai religius dalam novel Hafal Shalat Delisa karya Tere Liye. Dalam penarikan kesimpulan dan verifikasi peneliti encocokkan bukti nilai religius berupa kutipan yang terdapat pada novel. Selanjutnya dapat disimpulkan bahwa nilai religius dalam novel Hafalan Shalat Delisa sesuai dengan indikator nilai religius. Hasil analisis ini akan dijabarkan dalam bentuk teks dan diuji menggunakan triangulasi sumber.

\section{HASIL DAN PEMBAHASAN}

Nilai-nilai religius yang terdapat dalam novel Hafalan Shalat Delisa karya Tere Liye tersebut menyangkut pendidikan aqidah (keimanan), syariah (ibadah), dan akhlak (budi pekerti) dapat dipaparkan sebagai berikut.

\section{Nilai Pendidikan Aqidah (keimanan)}

Adapun nilai-nilai pendidikan Aqidah (keimanan) yang terdapat dalam novel Hafalan Shalat Delisa diantaranya sebagai berikut.

\section{a. Iman kepada Allah}

Ajaran keimanan kepada Allah dalam novel ini tertuang sebagai berikut.

Delisa mendekati Ummi, membuka setorannya pagi ini. Ummi menunggu. Delisa mulai membaca Ta'awudz dan bismillah pelan sambil memperbaiki kerudung birunya (Tere Liye, 2017).

\section{b. Iman kepada Malaikat}

Ajaran keimanan kepada malaikat dalam novel ini tertuang sebagai berikut.

Ya Allah, terban itu seketika membuncah bumi. Tanah bergetar dahsyat, menjalar merambat menggentarkan seluruh dunia radius ribuan kilometer. Bumi bak digoyang bumi raksasa. Dan... Ya Allah, air laut seketika bagai mendidih. Tersedot kedalam rekahan tanah maha luas itu. Tarian kematian semakin mengerikan. Aroma tragedi besar menggantung di langit-langit samudera. Ratusan ribu penduduk Aceh dan sekitarnya tidak tahu. Milyaran penduduk dunia belum tahu! Tetapi seribu malaikat bertasbih di atas langit Lhok Nga. Melesat siap menjemput (Tere Liye, 2017).

\section{c. Iman kepada Kitab}

Ajaran keimanan kepada kitab dalam novel ini tertuang sebagai berikut.

Ummi sedang mengajari Cut Aisyah dan Cut Zahra. Sedangkan Fatimah membaca Al-quran sendiri. Tidak lagi diajari Ummi. Ah, kak Fatimah bahkan setahun terakhir sudah khatam dua kali. Ini jadwal rutin mereka setiap habis shubuh. Belajar ngaji dengan Ummi, meskipun belajar ngaji TPA dengan Ustadz Rahman di meunasah (Tere Liye, 2017).

\section{d. Iman kepada Rasul}

Ajaran keimanan kepada rasul dalam novel ini tertuang sebagai berikut.

"Pernah ada sahabat Rasul, saking khusuknya shalat, kalajengking besar menggigit punggungnya dia tidak merasakan sama sekali... ya kalajengking 
besar..." Ustadz Rahman menggambar kalajengking besar itu dengan tangannya di udara. Bersuara seperti capit kalajengking yang menganga (Tere Liye, 2017).

\section{e. Iman kepada Takdir}

Ajaran keimanan kepada takdir dalam novel ini tertuang sebagai berikut.

Lihatlah, gadis kecil itu begitu damai. Wajahnya menyenangkan. Memberikan semua jawaban. Tak ada gunanya menyesali semua takdir Tuhan atas anak dan istrinya. Tak ada gunanya menyalahkan diri sendiri atas kejadian tersebut. Apalagi sumpah serapah dan berbagai kemarahan-kemarahan yang tidak jelas (Tere Liye, 2017).

\section{Nilai Pendidikan Syariah (Ibadah) \\ a. Perintah mengerjakan shalat}

Ajaran perintah mengerjakan shalat tertuang dalam novel ini sebagai berikut.

Delisa sebenarnya sekarang tak pernah absent ikut shalat maghrib, isya, dan shubuh bersama Abi. Bangun pagi bukan masalah besar baginya sekarang. Tetapi shalat Delisa tidak pernah sempurna. Tidak pernah lengkap. Bacaannya kebolak-balik, bahkan lupa sama sekali. Abi tidak seperti Ummi atau Kak Aisyah, Abi tidak membaca bacaan shalatnya keras-keras. Kecuali pas Al-fatihah dan surat pendek. Jadi selama shalat, Delisa hanya melakukan gerakannya saja (Tere Liye, 2017).

\section{b. Berzikir kepada Allah}

Ajaran berzikir kepada Allah tertuang dalam novel ini sebagai berikut.

Yang tidak rutin, shubuh itu, sehabis shalat ketika Ummi memimpin mereka berzikir.
Tiba-tiba Delisa maju ke depan. Merangkak dengan mukenah masih membungkus tubuhnya. Fatimah melotot menyuruhnya duduk kembali. Tetapi Delisa tidak peduli, tetap mendekati sajadah Ummi. Aisyah nyengir. Zahra tak memperhatikan melanjutkan zikir meniru suara Ummi (Tere Liye, 2017).

\section{Nilai Pendidikan Akhlak}

\section{a. Akhlak terhadap diri sendiri}

1) Sabar

Ajaran sikap sabar tertuang dalam novel ini sebagai berikut.

"Sabar... Anakku! Allah akan membalas semua kesabaran dengan pahala yang besar!'(Tere Liye, 2017).

2) Bersyukur

Ajaran bersyukur tertuang dalam novel ini sebagai berikut:

Abi memeluk Delisa sekali lagi. Mengusap matanya yang mulai basah. Ya Allah puji syukur. Engkau sungguh maha penyayang. Apapun itu, bungsunya ternyata selamat. Keajaiban itu masih ada. Abi untuk kesekian kalinya mengusap matanya yang semakin basah (Tere Liye, 2017).Menerima hidayah

Ajaran menerima hidayah tertuang dalam novel ini sebagai berikut:

Lihatlah, gadis kecil ini menderita lebih banyak, tetapi wajahnya teramat teduh. Gadis kecil ini sungguh menderita lebih banyak dibandingkan dirinya, namun wajahnya bercahaya oleh penerimaan. Pengertian itu datang kepada Prajurit Smith. Pemahaman yang indah! Hidayah itu akhirnya datang padanya (Tere Liye, 2017). 
b. Akhlak terhadap orangtua

1) Larangan durhaka terhadap kedua orang tua

Ajaran larangan durhaka terhadap kedua orang tua tertuang dalam novel ini sebagai berikut.

Giliran Aisyah. Ya Allah, Aisyah mentahmentah menolak bicara. "Aisyah, ayo... Abi nunggu nih!" Ummi menatap tajam. Aisyah tetap tak bergeming. "Aisyah, buruan!" (Tere Liye, 2017).

\section{2) Berbakti kepada kedua orang tua}

Ajaran berbakti kepada kedua orang tua tertuang dalam novel ini sebagai berikut.

Kak Aisyah dan Kak Zahra belum kelihatan, pasti sedang ngaji di meunasah, mereka jadwal mengajinya memang sore. Kak Fatimah sedang membantu Ibu membungkus pakaian- pakaian pesanan Ustadz Rahman di ruang depan (Tere Liye, 2017).

\section{3) Akhlak terhadap keluarga}

Ajaran akhlak terhadap keluarga tertuang dalam novel ini sebagai berikut.

Senin pagi. Itu berarti jadwal Abi menelpon setiap minggu langsung dari tanker minyak. Abi menelpon pakai telepon satelit. Mereka duduk di ruang keluarga menunggu (Tere Liye, 2017).

\section{4) Akhlak terhadap anak yatim}

Ajaran akhlak terhadap anak yatim tertuang dalam novel ini sebagai berikut.

Setiap kali Abi pulang, Tiur yang tiga rumah dari rumah mereka, selalu mendapat hadiah-sama banyaknya dengan hadiah Delisa (dan Delisa tidak protes seperti Kak Aisyah). Tiur juga selalu ikut bersama kalau Abi mengajak mereka jalanjalan(Tere Liye, 2017).
Dalam penelitian ini peneliti dalam menguji keabsahan data menggunakan triangulasi sumber. Triangulasi sumber digunakan peneliti untuk menguji sejauh mana hasil analisis dalam penelitian dengan pendapat berbagai narasumber. Narasumber yang dipilih terdiri dari 3 bidang yaitu dari guru sekolah dasar, orang tua siswa sekolah dasar, siswa sekolah dasar.

\section{Pembahasan}

Hasil penelitian menurut dari berbagai narasumber yang terdiri dari dua guru sekolah dasar, dua orang tua siswa, dan dua siswa sekolah dasar menunjukkan bahwa di dalam novel Hafalan Sholat Delisa sudah mencerminkan nilai-nilai religius. Nilai-nilai religius yang terkandung di dalam novel Hafalan Sholat Delisa adalah (1) nilai pendidikan Aqidah (keimanan) yang meliputi iman kepada Allah, iman kepada malaikat, iman kepada kitab, iman kepada rosul, dan iman kepada takdir; (2) nilai pendidikan Syariah (ibadah) yang meliputi mengerjakan shalat, menuntut ilmu, beramal dengan tulus ikhlas, berdzikir kepada Allah, berdoa kepada Allah; (3) nilai pendidikan Akhlak (budi pekerti) yang meliputi akhlak terhadap diri sendiri, akhlak terhadap orang tua, akhlak terhadap keluarga. akhlak terhadap saudara, akhlak terhadap sesama, akhlak terhadap anak yatim.

Novel Hafalan Shalat Delisa merupakan salah satu novel karya Tere Liye. Novel tersebut berbasis anak-anak yang di dalamnya menggambarkan lingkungan keluarga yang variatif dan inspiratif. Novel ini termasuk pada novel yang dapat mengajarkan para pembaca untuk selalu bersabar dalam menghadapi persoalan. Sikap religius para tokoh di novel tersebut dapat dijadikan teladan bagi pembaca. Rutinitas shalat berjama' ah dan mengaji setiap sore dapat dijadikan panutan bagi manusia. Novel tersebut mengajarkan kepada kita untuk mensyukuri nikmat dari Tuhan Yang Maha Esa dengan cara menjalankan segala aturan-Nya. 


\section{SIMPULAN DAN REKOMENDASI}

Nilai religius yang terdapat pada novel Hafalan Shalat Delisa karya Tere Liye adalah nilai pendidikan Aqidah (keimanan), nilai pendidikan Syariah (ibadah), dan nilai pendidikan Akhlak (budi pekerti).

Saran penelitian ini yaitu kepada orang tua saat ini harus mampu membaca novel Hafalan Shalat Delisa karya Tere Liye karena didalamnya terkandung nilai-nilai religius yang sangat baik untuk ditanamkan pada anak-anak sejak dini, guru dapat mengimplementasikan nilai-nilai yang terkandung dalam novel Hafalan Shalat Delisa karya Tere Liye pada saat proses belajar mengajar dikelas. Novel Hafalan Shalat Delisa karya Tere Liye dapat dijadikan sebagai sarana memperkaya referensi buku-buku di perpustakaan sekolah. Para pembaca seyogyanya berkenan membaca, memahami, meneladani serta mengimplementasikan nilai-nilai religius yang terdapat pada novel Hafalan Shalat Delisa karya Tere Liye dalam kehidupan sehari-hari. Selain itu juga bisa digunakan untuk menanamkan nilai religius tersebut pada anak- anak yang ada di lingkungan pembaca. Karena penanaman nilai religius pada anak bukan hanya menjadi tanggung jawab orang tua saja, melainkan orang-orang yang ikut bersosialisasi dengan anak.

\section{DAFTAR PUSTAKA}

Agus, W. (2013). Pendidikan Karakter Berbasis Sastra. Pustaka Pelajar.

Burhan, N. (2005). Sastra Anak. Gadjah Mada Univercity Press.

Burhan, N. (2012). Teori Pengkajian Fiksi. Gadjah Mada Univercity Press.

Endang, H. W. (2016). Teori dan Sejarah Sastra Indonesia. UPI PRESS.

Fitri, D., \& Eka, S. S. (2019). Analisis Pelaksanaan Program PPK Melalui Kegiatan Tadarus Dalam Mengembangkan Nilai Religius. Journal for Lesson and Learning Studies, $2,2$.

Fitriana, N. H. (2013). Nilai-Nilai Pendidikan Islam Dalam Film Hafalan Sholat Delisa
Karya Sony Gaokasak. UIN Sunan Ampel Surabaya.

Gunawan, H. I. (2020). Nilai Religius dalam Novel Hafalan Shalat Delisa Karya Tere Liye dan Implikasinya terhadap Pembelajaran Apresiasi Sastra di Sekolah Menengah Atas (Kajian Struktural Genetik dan Analisis Isi). Eduka: Jurnal Pendidikan, Hukum, Dan Bisnis, 5(1), 10-20.

Kaelan. (2014). Pendidikan Pancasila. Paradigma. Madjid, N. (2017). Islam dan Doktrin Peradaban. Yayasan Paramadina.

Mangunwijaya. (2017). Sastra dan Religiositas. Kansius.

Prastica, D., \& Wulandari, Y. (2020). Diksi dan gaya kalimat dalam novel Hafalan Shalat Delisa karya Tere Liye. Pena Literasi, 2(2), 64-69.

Regar, H. B., Nurizzati, N., \& Hamidin, H. (2012). Nilai-nilai Religius dalam Novel Hafalan Shalat Delisa karya Tere-Liye. Jurnal Bahasa Dan Sastra, 1(1), 92-100.

Subijantoro Atmosuwito. (2017). Perihal Sastra dan Religiusitas dalam Sastra. Sinar Baru.

Sudarsono. (2017). Sepuluh Aspek Agama Islam. Rineka Cipta.

Sugiyono. (2017). Metode Penelitian Pendidikan. Alfabeta.

Tere, L. (2017). Hafalan Shalat Delisa. Republika.

Tim Penyusun Kamus. (2015). Kamus Besar Bahasa Indonesia Pusat Bahasa. PT. Gramedia Pusat Bahasa.

Wanispa, E., \& Hidajati, E. (2018). Nilai pendidikan berkarakter dalam novel Hafalan Sholat Delisa karya Tere Liye: Kajian sosiologi sastra. Jurnal Ilmiah Bina Edukasi, 11(01), 13-25. 